\title{
Author Correction: Discovering the genes mediating the interactions between chronic respiratory diseases in the human interactome
}

\author{
Enrico Maiorino (D, Seung Han Baek, Feng Guo (D), Xiaobo Zhou (D), Parul H. Kothari, Edwin K. Silverman, \\ Albert-László Barabási (1), Scott T. Weiss, Benjamin A. Raby \& Amitabh Sharma (D)
}

Correction to: Nature Communications https://doi.org/10.1038/s41467-020-14600-w, published online 10 February 2020.

The original version of this Article omitted a reference to previous work in "Garcia-Vaquero, M.L., Gama-Carvalho, M., Rivas, J.D.L. et al. Searching the overlap between network modules with specific betweenness (S2B) and its application to cross-disease analysis. Sci. Rep. 8, 11555 (2018)". This has been added as a reference 31 in the second sentence of the third paragraph in Results subsection "Flow centrality between modules." as follows: "Flow centrality is a betweenness measure that is parametric on a source set and destination set of nodes, and its coverage spans exclusively the shortest paths connecting the two modules, instead of the whole network, similarly to a recently proposed measure called Double Specific Betweenness (S2B) [ref. 31]". This has been corrected in the PDF and HTML versions of the Article.

Published online: 19 April 2021

\footnotetext{
(c) Open Access This article is licensed under a Creative Commons Attribution 4.0 International License, which permits use, sharing, adaptation, distribution and reproduction in any medium or format, as long as you give appropriate credit to the original author(s) and the source, provide a link to the Creative Commons license, and indicate if changes were made. The images or other third party material in this article are included in the article's Creative Commons license, unless indicated otherwise in a credit line to the material. If material is not included in the article's Creative Commons license and your intended use is not permitted by statutory regulation or exceeds the permitted use, you will need to obtain permission directly from the copyright holder. To view a copy of this license, visit http://creativecommons.org/licenses/by/4.0/.
}

(C) The Author(s) 2021 